\title{
ARTICLE
}

\section{Innovation Management MADU PELAWAN (Integrated House of Integrated Entrepreneurship Development and Services) in Central Bangka Regency}

\author{
Iwan Kurniawan \\ STIE IPWI Jakarta | H. Baping Street No.17, Ciracas, Jakarta \\ 凶iwanipwija@gmail.com
}

\section{OPEN ACCESS}

Citation: Iwan Kurniawan. Innovation Management MADU PELAWAN (Integrated House of Integrated Entrepreneurship Development and Services) in Central Bangka Regency. Ijori Journal Vol. 1 No. 4 (2021): 16-24. https://doi.org/10.52000/ijori.v1i4.28

e-ISSN : 2775-7641

Accepted: November 30 th, 2021

(c) The Author(s)

\section{cc)(\$)}

This work is licensed under a Creative Commons Attribution-NonCommercialShareAlike 4.0 International License.

\begin{abstract}
This research is about management Independent Entrepreneurial Development and Service innovation as one of the real actions of the government in an effort to improve the community's economy through empowering IKM (Small and Medium Industries). The focus of this research is the management of Independent Entrepreneurial Development and Service innovation carried out by Central Bangka Regency. This study used qualitative research methods. The population in this study is an area that has made innovations in the development and service of independent entrepreneurs. Meanwhile, the research subject is in Central Bangka Regency with an innovation called Madu Pelawan (Integrated House for Independent Entrepreneurship Development and Services). The results showed that the Honey Innovation Management of Pelawan (Integrated House for Development and Independent Entrepreneur Services) in Central Bangka Regency succeeded in making real changes. The existence of the Product Development House (RPP) has made significant changes to the growth and development of IKM/UKM in Central Bangka Regency. As it is very easy to find IKM products that already have a good label in accordance with the required provisions, it is very easy to find products that have used food grade packaging, many IKM products are found that are accepted and marketed in gift shops and modern stores, almost all packaged food products have marketing permits, the reach of loan services has become easier with the facilitation of counseling, many IKM products have promotional media such as the 7/9 booklet, some IKM actors already have process and promotional videos, and 5 IKM Centers have been formed.
\end{abstract}

Keywords : Innovation, Small and Medium Industry, Public Service, Local Government, Community

\section{Preliminary}

One of the strategic steps taken by the government in an effort to improve product quality and revive the industrial sector. This research is about management Independent Entrepreneurial Development and Service innovation as one of the real actions of the government in an effort to improve the community's economy through empowering IKM (Small and Medium Industries). Where this can be done one of them by increasing the competence of Human Resources in IKM such as technical guidance on improving product quality. Of course, this is intended so that IKM actors can understand the implementation of a good quality management system, production management, SNI certification process, product testing, and marketing strategies. Through this innovation program, of course, it is hoped that it can improve the image of SMEs and gain the trust of customers.

A business that produces various types of products from SMEs is an economic activity that processes and even changes the form of basic goods mechanically or by 
hand so that they become finished or semi-finished products and even become inferior products into higher quality goods to users or consumers. According to data from the Central Statistics Agency (BPS) on economic development since the first 3 Months in 2020 , it shows that there has been a national economic deceleration of around $2.97 \%$. The results of the report from the Buku Warung website also mention that there has been a decline in income of up to $90 \%$ in Small and Medium Industries (IKM) over the last four months (Santosa, 2020).

Business competition or competition Business is certainly something that cannot be avoided by business actors themselves with the aim of surviving in carrying out their business. This criterion is a big problem for economic entrepreneurs, especially for SMEs, even though it is now a government program. Business actors assume that business rivalry requires basic innovation and special strategies in creating competition for quality human resources, mastering technology, capital adequacy and having a conducive environment (Santosa, 2020). An increasingly modern and well-established society has a myriad of expectations, such as a comfortable living and work environment, the existence of an adequate public area, and the ease of managing all forms of public services. (Suhendra, 2017). One way that is packaged by the industry today is to promote quality, cheap, and affordable goods to its consumers. So that competition must exist in every industry in order to maintain the quality, this also applies to IKM in Indonesia in order to create cluster-based competition (Asmara \& Rahayu, 2013). Thus, after the formation of a continuous competition cluster, new knowledge will be created in the form of the local product development strategy (Tambunan, 2012). With the birth of a cluster, it will naturally foster innovation which will eventually lead to the formation of collective innovation power and business area rivalry (Nuryanto, 2016). These IKM clusters will later become one of the drivers of the local economy, although in practice there are still many obstacles faced by IKM actors themselves and the government (Ratnasari, 2013; Santosa, 2020).

Global challenges and advances in information technology certainly bring changes to the life and business flow of an organization or company. This makes it important for innovation strategies to help companies survive change (Sasono \& Y, 2014). According to Peter F. Drucker in Sasono \& Y (2014) A good organization is one that can see opportunities in situations of uncertainty. In one of his books
"Management Challenges for the 21st Century," Drucker mentions several factors that support organizations to withstand change. First,

Flexibility: Changes in the environment make companies have to be flexible in making strategies. Companies in essence must be adaptive and ready to face change in order to survive. The strategy includes policies, marketing, operations, and others. Second, Focus on opportunities: A company must have a clear focus, this is related to the company's vision and mission. The vision and mission used by the company will ultimately affect the company's performance. The strategy made by the company must also be clear, for example what products will be made or sold, who are the partners who can help and what are the achievement targets for the next year. Third, Facilities: A company must provide facilities that support the company's performance, both equipment, machinery, resources and technology. This is aimed at increasing company productivity and preparing to face global challenges. Fourth, Managing knowledge: Companies must continue to improvise on changes by managing the knowledge held by the company into more useful knowledge. Knowledge management can be obtained in various ways, such as employee knowledge and research that has been developed. And fifth, Innovation: Innovation is very important in the development of a company. Companies must not stop to innovate. Innovation can be done by combining existing knowledge and creativity within the company and supported by the facilities available in the company. Companies must continue to improvise on changes by managing the knowledge owned by the company into more useful knowledge. Knowledge management can be obtained in various ways, such as employee knowledge and research that has been developed. And fifth, Innovation: Innovation is very important in the development of a company. Companies must not stop to innovate. Innovation can be done by combining existing knowledge and creativity within the company and supported by the facilities available in the company. Companies must continue to improvise on changes by managing the knowledge owned by the company into knowledge that is even more useful. Knowledge management can be obtained in various ways, such as employee knowledge and research that has been developed. And fifth, Innovation: Innovation is very important in the development of a company. Companies must not stop to innovate. Innovation can be done by combining existing knowledge and creativity within the company 
and supported by the facilities available in the company. such as employee knowledge and research that has been developed. And fifth, Innovation: Innovation is very important in the development of a company. Companies must not stop to innovate. Innovation can be done by combining existing knowledge and creativity within the company and supported by the facilities available in the company. such as employee knowledge and research that has been developed. And fifth, Innovation: Innovation is very important in the development of a company. Companies must not stop to innovate. Innovation can be done by combining existing knowledge and creativity within the company and supported by the facilities available in the company.

The focus of this research is focusing on the innovation management of Independent Entrepreneurial Development and Services carried out by Central Bangka Regency named Madu Pelawan (Integrated House for Independent Entrepreneurial Development and Services). Small and Medium Industries or more popularly known as IKM so far have played an important role in the economic development of the community. However, the management is still limited to traditional conventional with relatively unorganized management. In fact, if managed properly, Small and Medium Industries will become one of the pillars of the community's economic strength. Even though the results are small-scale by targeting the needs of families, the cottage industry can strengthen the economic resilience of the community.

Innovation is a new discovery that is different from the previous one in the form of thoughts and ideas that can be developed and implemented so that the benefits are felt (Hutagalung \& Hermawan, 2018). Several important factors that influence the development of local government innovation are human resources, community participation, leadership aspects, infrastructure, information management, and the (private) business environment.

Innovation management itself is about how companies manage innovation within the company, including planning, processes, to the implementation stage. Innovation management will pave the way for the company's future growth and competitive success (Sasono \& Y, 2014). Innovation management is an important instrument to increase the innovation capacity of SMEs. Where, SMIs need to adjust several aspects of the innovation management system in order to ensure that long-term innovation can be a success for the progress of SMIs. We realize that serious efforts are needed to raise the quality of local government decisions and actions to be more effective and efficient through innovative breakthroughs. It can be stated more explicitly that innovation is needed by the Regional Government to improve the quality of the decisions and actions it produces so that the impact can improve the welfare of the local community (Wicaksono, 2018).

Research related to the innovation management of Independent Entrepreneurial Development and Services in IKM (Small and Medium Industries) has been carried out by previous researchers. As research conducted byGemina et al. (2016). Where, in his research explained that the role of entrepreneurship through business motivation and business ability to achieve business success is not optimal. While the problems faced by small and medium industries are multi-dimensional, including internal problems of each business unit, external problems in relation to suppliers (suppliers), buyers (buyers) or consumers and competitors, problems related to empowerment efforts as well as the problem of economic globalization in connection with the treatment of free trade and advances in information technology. Internally, SMEs which are dominated by very small scale businesses (micro enterprises) are faced with the problem of limited human resources such as low levels of education making their business insight very narrow,

Then, Karamoy et al. (2016) also conducts research related to Small and Medium Industries. His research explains that in facing the competition of the Indonesian industrial world, it must be ready and competitive, therefore efforts in planning, implementing, organizing and controlling in companies or Small and Medium Industries (IKM) need to be improved in order to achieve goals and increase competitiveness. The main and distinguishing feature between companies and Small and Medium Industries (IKM), is their production system, which is more specifically in the production process. Before the stage of the production process, there is also a layout that is closely related to the production process because it involves effectiveness and efficiency in a company or IKM business. The involvement of production factors is very important to be directed to the goals and objectives that have been set, so that it has a huge impact on the effectiveness of the company's production process and the IKM actors. The production process can take place continuously if the need for raw materials and placement of the right layout for the implementation of the production process can be met. 
Research related to Small and Medium Industries was also carried out by Prasnowo et al. (2017) strategy focused. Strategy as a process of determining the plans of top leaders that focuses on the long-term goals of the organization, accompanied by the preparation of a method or effort on how to achieve these goals. The development of small and medium industries is an effort to improve the economy because of its enormous potential in driving the national economy. Small and medium industries have a big role in the economy because many people depend on SMEs for their lives.

Other than that, Asmanita (2018) in his research explained that the policy of developing new entrepreneurs is an inseparable part of the goals to be achieved from strengthening the people's economy as mandated by the constitution Article 33 of the 45th Constitution concerning the realization: "the economic system is structured as a joint effort based on kinship that guarantees justice and prosperity for all the people of Indonesia" (Article 33 paragraph 1 of the 1945 Constitution); "Production branches which are important for the state and which affect the livelihood of the people are mostly controlled by the State" (Article 33 paragraph 2 of the 1945 Constitution); mandate that every citizen has the right to work and a decent living" (Article 27 paragraph 2 of the 1945 Constitution). For the local government, innovation is a source of improvement in various aspects of social and economic life where economically is the key word to increase regional competitiveness. For now, increasing regional competitiveness through various innovations, both innovation in production processes and product innovation as a forum for developing small and medium industries, can be said to be no longer something exclusive but has a basic need for regions to increase competitiveness. The openness of the country's economy to other countries, both globally and regionally, such as the ASEAN Economic Community (MEA) in the Southeast Asian region has the consequence of regional readiness to increase regional competitiveness so that the region can compete with other regions in Indonesia, other countries in ASEAN, and be able to penetrate world market. For now, increasing regional competitiveness through various innovations, both production process innovation and product innovation as a forum for developing small and medium industries, can be said to be no longer something exclusive but has a basic regional need to increase competitiveness. The openness of the country's economy to other countries, both globally and regionally, such as the ASEAN Economic
Community (AEC) in the Southeast Asian region has the consequence of regional readiness to increase regional competitiveness so that regions can compete with other regions in Indonesia, other countries in ASEAN, and are able to penetrate world market. For now, increasing regional competitiveness through various innovations, both innovation in production processes and product innovation as a forum for developing small and medium industries, can be said to be no longer something exclusive but has a basic need for regions to increase competitiveness. The openness of the country's economy to other countries, both globally and regionally, such as the ASEAN Economic Community (MEA) in the Southeast Asian region has the consequence of regional readiness to increase regional competitiveness so that the region can compete with other regions in Indonesia, other countries in ASEAN, and be able to penetrate world market.

Not only that, Yudianto \& Nurpratama (2021) in his research also explains that innovation management is a tool used by managers and organizations or companies to develop products and organizational innovations or in other words innovation management is the management and organization of a process. As explained by (Muflihah \& Susanto, 2017) and (Andhika, 2018), namely that the success of implementing local government innovations is strongly influenced by the collaboration of institutional arrangements, policy actors, and the community. The quality of human resources is very influential on the growth of innovation, both in terms of the number and type of innovation itself, especially the ability of leaders to organize their work environment to be more innovative (Yudha \& Susanto, 2019).

In contrast to previous research, in this study the author focuses more on innovation management such as what was done by Central Bangka Regency in its innovation called Madu Pelawan (Integrated House for Independent Entrepreneurial Development and Services). Where in realizing this innovation it is necessary to have mature innovation management and of course carried out by the local government and supported by community participation in order to create a stable economy as a solution in realizing economic problems that occur in Central Bangka Regency.

This research is considered important because in the midst of the influence of globalization which spreads the economic gap between the class and the small and medium class, the people's economic 
business with its various principles should be read as a business that is the main driver of the nation's economy. Inevitably, the people's economy has also become an important job for local governments to move the community's economy which is rooted in people's daily activities. Through various small and medium enterprises, the wheels of the family economy as the smallest unit will move dynamically. Local governments are also required to provide full support for people's economic development efforts.

\section{Research Methods}

This study uses a qualitative method. Qualitative research method is a method used to answer research problems related to data in the form of narratives sourced from interviews, observations, document multiplication. In order to properly describe the approach and type of research, the presence of researchers, research locations, data sources, data collection techniques, data analysis, and checking the validity of the findings in a research proposal and/or report, a good understanding of each of these concepts is required (Dr. Wahidpure, 2017).

Qualitative methods develop when there is a change in the paradigm in viewing a reality, phenomenon, or observed phenomenon. During the paradigm shift, social reality has been seen and understood as holistic, complex, dynamic, and full of meaning (Zamili, 2015; Sugiyono, 2017).

In this study, data collection was also carried out through searching various sources which were then processed and described in narrative form according to data needs. The population in this study is an area that has made innovations in the development and service of independent entrepreneurs. Meanwhile, the research subject is in Central Bangka Regency with an innovation called Madu Pelawan (Integrated House for Independent Entrepreneurship Development and Services).

\section{Results and Discussion}

People's economic empowerment is an activity that utilizes various small and medium-scale community economic activities that are directly in contact with efforts to improve the economy of middle and small groups of people. The people's economy itself is the embodiment of the Pancasila Economy which is outlined by the state ideology, namely Pancasila.

Mubyarto (1997) said that the Pancasila economy which was later realized in the practical field into a people's economy was a moral economic activity, did not require a strong command from the government, had a familial pattern, sought mutual prosperity, and upholds the spirit of solidarity in order to achieve social justice. Thus, if you look closely, the people's economy emphasizes the aspects of togetherness and justice in running an economic business.

One of the focuses of attention is the Small and Medium Industry which is still managed incidentally or regularly with simple management. Home industry in the form of folk snacks was chosen in this program with several important considerations.

First, this empowerment is in order to realize the OVOP (One Village One Product) national program so that it is hoped that every village/kelurahan has Small and Medium Industry products that are the mainstay and unique to the area.

Second, Small and Medium Industries are inherent in people's lives and are secondary foods that are always present in everyday life. As a complementary food outside of meals, Small and Medium Industries cannot be separated from people's daily lives. This means that IKM products can be categorized as mandatory consumption and will always be there to color the culinary dynamics of society at various levels.

Third, Small and Medium Industry is an activity carried out by productive groups with simple tools and capital so that it is not too difficult to develop these skills. The more productive groups who look at this business, the higher the promotion and consumption will be. The high level of supply, promotion, and consumption will have an effect on better competition so that there is a demand for better professionalism to manage and prepare Small and Medium Industry products.

Fourth, Small and Medium Industry products can be packaged more modernly with better absorption in society. If so far Small and Medium Industries seem very simple and only reach small communities, with better management, Small and Medium Industries can be developed to penetrate a wider market, namely the classy community market, hotels, offices, seminars seminars, and better levels. Quality snacks, good management, good marketing and promotion will guarantee the conversion of a cottage industry to a classy industry.

This activity thus becomes important for efforts to empower the people's economy and is an effort to boost the acceleration of the economic power of the community. In this empowerment activity, it is possible to have a comprehensive empowerment design, 
starting from concept maturation, training, providing capital, mentoring, to the evaluation stage.

In relation to the development of a people's economy based on the Pancasila Economy, Siswanto (2007; see also Boediono, 1981) says that the creative potential of the community is developed as long as it does not harm the public interest. The district government wants to ensure that government intervention can strengthen the community's economy by stimulating the creative potential and improvisation of the community to make breakthroughs that have economic value.

District governments as regulators as well as facilitators in terms of developing and empowering the people's economy are required to carry out various strategic policies to achieve the planned goals in the short, medium and long term.

The Central Bangka Regency Government especially through the Department of Industry, Trade, Cooperatives and MSMEs realizes how Small and Medium Industries have a very important and significant role in moving the wheels of the regional economy in general and the people in particular.

Small and Medium Industry (IKM) is one of the economic links that is resistant to various crises, especially the economic crisis. SMEs are still able to survive even though at the same time so many large companies have collapsed due to the economic crisis. That IKM is a labor-intensive economic chain and it comes from the community and to meet the needs of the community makes IKM more able to survive in the face of various economic crises.

IKM is also present as a pillar of the village economy by standing up and then embracing local workers so that it can be expected that their presence is proof of the existence of a people's economy that provides tangible evidence for the welfare of small communities. In addition to being considered positive from an economic perspective, IKM also has a positive role in educating people to think and be able to be economically independent and reduce latent dependence to only think as workers. The presence of IKM in the community is able to make it a real example that entrepreneurship and self-employment are a necessity for a better and dignified life.

SMIs also play an important role in meeting the needs of the community, both quantitatively and qualitatively, which are sometimes unable to be met by large industries due to their uniqueness which sometimes differs from one place to another.
The Central Bangka Regency Government through Disperindagkop-UMKM is very aware of the importance of IKM and sees IKM as one of the regional economic chains that really must be developed and empowered seriously and planned to get maximum results. The growth and development of SMIs are the two things that are most considered in this IKM development goal. Disperindagkop-UMKM Central Bangka Regency hopes to achieve a proud percentage in the calculation of entrepreneurial growth so that it can approach the figure of $2 \%$ of the population of Central Bangka which is a national reference for realizing a more prosperous society.

In running their business, IKM actors face various problems where the government must be present to help these problems. One of the innovations made by the Department of Industry, Trade, Cooperatives and SMEs is to form a forum or sub-unit of work that is able to overcome various problems of SMEs, including: 1). Licensing, 2). Counseling Assistance, 3). Consultancy, 4). Label and Packaging Design, and 5). Product marketing.

Departing from these needs, a Product Development House (RPP) was created to answer all these needs. In addition to forming the RPP which has been formed from the embryo of the Packaging Clinic which has been established since 2015, the Department feels it is increasingly important to raise the existing service standards by completing the various needs of existing facilities and infrastructure.

Central Bangka Regency is a new expansion district which was only established on February 25, 2003 based on Law Number 5 of 2003. The establishment of Central Bangka Regency was based on the desire of the community to obtain more effective and efficient public services. One of the main services expected by the community to be faster is services in the economic field. In 2014 the number of IKM (Small and Medium Industries) spread across all sub-districts in Central Bangka Regency was 2,658 IKM.

As a newly developing district, accelerations are felt to be absolutely necessary to solve the economic problems of the community which have begun to reach the end of the economic glory in the mainstay sector, namely mining and tin processing.

The independence and resilience of the community's economy is one of the pillars that is considered important to immediately spur growth and development. Because SMEs are one of the economic segments that have been proven to be more resistant to crises both locally and regionally and even globally. 
Some of the main problems faced by the small business community at that time included first, capital. Where, the community feels the need to facilitate access to capital with a low interest rate and easier administrative requirements. Second, Business Assistance and Counseling. As people who are just learning entrepreneurship, they really need guidance and direction in running their businesses so that they can improve their business qualifications from micro to small, medium and large businesses. The community needs the direct presence of the government in assisting the businesses they run. Third, Label and Packaging. As many as 1. 200 SMIs or about $45 \%$ are Food SMIs and the products produced by these SMEs do not yet have appropriate labels and packaging as regulated in the Food Law on labels and packaging. Fourth, Product Marketing. The community needs wider marketing access in order to increase its sales volume from initially only at the local market level to expanding regionally. And fifth, business licensing / legality. Where, the community needs access to definite permits, both business licenses and distribution permits for products that have been produced. The community needs wider marketing access in order to increase its sales volume from initially only at the local market level to expanding regionally. And fifth, business licensing/legality. Where, the public needs definite access to permits, both business licenses and distribution permits for products that have been produced. The community needs wider marketing access in order to increase its sales volume from initially only at the local market level to expanding regionally. And fifth, business licensing/legality. Where, the community needs access to definite permits, both business licenses and distribution permits for products that have been produced.

This main problem then makes the business development of IKM and SME actors in Central Bangka Regency move slowly in an effort to accelerate economic growth after tin mining that is already in sight.

A program of economic acceleration activities was carried out in 2014 in Central Bangka Regency, where the program is planned to be based on integrated services to the community so that the various main problems above can be resolved immediately. The service must also be in the midst of the community with easy access and easily accessible by business actors. A service that is present right at the doorstep of IKM and SME business locations.
The objectives of this Madu Pelawan innovation are, among others, to provide Label and Packaging services, to provide Consultancy Services, to conduct Marketing Services, to provide Mentoring and Counseling Services, to conduct IKM Product Promotion Services, and to perform IKM Licensing Services.

While the benefits of this innovation are the service of application for product packaging labels for IKM products in Central Bangka, the service of IKM consulting services, increased marketing facilitation of IKM products, assistance and counseling services for IKM actors, and increased promotion of IKM products.

The results of the implementation of the Product Development House, among others, are the increasing number of types/variants of products produced by the IKMs, and the better packaging of products for the IKMs. The number of labels that have been facilitated by the Product Development House from 2014 is 533 product labels, and the number of unlabeled and packaged products circulating in the community has decreased significantly, which is monitored from the results of monitoring of circulating goods both by DIPERINDAGKOP-UKM and by the DINKES and BPOM. In addition, 90 SMI actors who have obtained Food Safety Extension Certificate Facilities, and 107 SMIs who have obtained Halal Certificate Facilities. IKM actors can buy packaging at the Product Development House and obtain supplier information through the Product Development House.

\section{Conclusion}

Innovation Management Madu Pelawan (Integrated House for Independent Entrepreneurial Development and Services) in Central Bangka Regency has succeeded in making real changes. The existence of the Product Development House (RPP) has made significant changes to the growth and development of IKM/UKM in Central Bangka Regency. Some significant changes can be seen through the following matrix:

\begin{tabular}{lll}
\hline No & Pre-RPP Conditions & \multicolumn{1}{c}{ Post-RPP Conditions } \\
\hline 1 & There are still very & It is very easy to find IKM \\
many IKM products that & products that already have \\
appear without a label & good labels that comply with \\
or with a label that is not & the required conditions \\
in accordance with the & \\
required conditions & \\
2 There are still many & It's very easy to find \\
products that have not & products that use food grade \\
used good and correct & packaging \\
packaging &
\end{tabular}




\begin{tabular}{cll}
\hline No & \multicolumn{1}{c}{ Pre-RPP Conditions } & \multicolumn{1}{c}{ Post-RPP Conditions } \\
\hline 3 & $\begin{array}{l}\text { There are no local } \\
\text { products that enter the } \\
\text { gift shop and modern } \\
\text { shop }\end{array}$ & $\begin{array}{l}\text { There have been many IKM } \\
\text { products that have been } \\
\text { accepted and marketed in } \\
\text { gift shops and modern } \\
\text { stores }\end{array}$ \\
\hline 4 & $\begin{array}{l}\text { Many products do not } \\
\text { have a business license } \\
\text { and distribution permit }\end{array}$ & $\begin{array}{l}\text { Almost all packaged food } \\
\text { products have a distribution }\end{array}$ \\
\hline 5 & $\begin{array}{l}\text { Difficult access to loan } \\
\text { services }\end{array}$ & $\begin{array}{l}\text { The range of loan services is } \\
\text { made easier with the } \\
\text { facilitation of counseling }\end{array}$ \\
\hline 6 & $\begin{array}{l}\text { It is difficult to find } \\
\text { business actors who } \\
\text { have promotional } \\
\text { media }\end{array}$ & $\begin{array}{l}\text { There are already many IKM } \\
\text { products that have } \\
\text { the 7/9 booklet }\end{array}$ \\
\hline 7 & $\begin{array}{l}\text { SMEs do not have } \\
\text { process and promotion } \\
\text { videos }\end{array}$ & $\begin{array}{l}\text { Some SMI actors already } \\
\text { have process and promotion } \\
\text { videos }\end{array}$ \\
\hline 8 & $\begin{array}{l}\text { Not yet formed IKM } \\
\text { center }\end{array}$ & $\begin{array}{l}5 \text { IKM Centers have been } \\
\text { formed }\end{array}$ \\
\hline
\end{tabular}

\section{Acknowledgments}

The researcher expresses his deepest gratitude to the parties who contributed to the writing of this journal, so that the research can be completed as much as possible.

\section{References}

Andhika, LR (2018). Element and Factor Governance Innovation in Government Public Service. Journal of Balitbangda, 6(3), 207-222.

Asmanita. (2018). Analysis of the Innovation Potential of Small and Medium Industries in the City of Padang. Sriwijaya Journal of Management and Business, 15(3), 173-182. https://doi.org/10.29259/jmbs.v15i3.5713

Asmara, AY, \& Rahayu, S. (2013). Improving the competitiveness of small and medium-sized industries through innovation and the use of social networks: lessons from a software industry cluster in India. Sustainable Competitive Advantage (SCA), 3(1).

Dr. Wahidpur, MP (2017). EXPOSURE OF QUALITATIVE RESEARCH METHODS. Lecturer of the Faculty of Tarbiyah and Teacher Training at UIN Maulana Malik Ibrahim Malang, 549, 40-42.

Gemina, D., Silaningsih, E., \& Yuningsih, E. (2016). The Effect of Business Motivation on Business Success with Business Ability as a Mediation Variable in the East-Indonesian Priangan Small and Medium Snack Industry. Journal of Technology
Management, $\quad$ 15(3), 297-323. https://doi.org/10.12695/jmt.2016.15.3.6

Hutagalung, SS, \& Hermawan, D. (2018). Building Local Government Innovation, 1-215. Taken from http://repository.lppm.unila.ac.id

Karamoy, RP, Tumade, P., \& Palandeng, ID (2016). IMPLEMENTATION OF PRODUCTION SYSTEM IN SMALL MEDIUM INDUSTRY (CASE STUDY ON: SMALL MEDIUM INDUSTRY "SME" IN TOULIANG OKI VILLAGE). Scientific Journal of Efficiency, 16(2), 560-570.

Muflihah, Y., \& Susanto, TD (2017). Factors Influencing Citizens and Governments in E-Government Adoption: A Systematic Review. Journal of Information Technology and Computer Science, 4(4), 304-310. https://doi.org/10.25126/jtiik.201744366

Nuryanto, N. (2016). Optimizing the Export Performance of MSME Furniture in Central Java through the Indonesia National Single Window (INSW) application. Sens2.

Prasnowo, MA, Khomaruddin, A., \& Hidayat, K. (2017). Strategy for the Development of Small and Medium Industry Center for Crackers Production. Teknika: Engineering and Science Journal, 1(1), 17. https://doi.org/10.51804/tesj.v1i1.64.17-24

Ratnasari, A. (2013). The Role of Small and Medium Industries (IKM) in Employment Absorption in Ponorogo Regency. Journal of Economic Education (JUPE), 1(3).

Santosa, A. (2020). Development of the Creative Economy of Small and Medium Industries in Serang City during the Covid-19 Pandemic. Syntax Literate: Indonesian Scientific Journal, 5(11), 1257-1272.

https://doi.org/http://dx.doi.org/10.36418/syntax -literate.v5i11.1730

Sasono, E., \& Y, R. (2014). The Role of SMEs in the Economic Sector. Journal of Stie Semarang, 6(3), 74-90.

Sugiyono. (2017). Qualitative Research Methods. For Research that is: Explorative, Enterative, Interactive, and Constructive. Bandung: Alphabeta.

Suhendra, A. (2017). Local Government Readiness in Realizing Smart Cities in Bandung and Surabaya. Renewal Dimensions, 1(1), 1-9. https://doi.org/10.21787/mp.1.1.2017.1-9

Tambunan, TTH (2012). The role of micro and small enterprises in poverty alleviation in the regions. 
Journal of Bina Praja: Journal of Home Affairs Governance, 4(2), 73-92.

Wicaksono, KW (2018). Typology of Public Sector Innovations in Three Innovative Programs of the Surabaya City Government (A Reflective Review of Three Public Service Innovations of the Surabaya City Government in 2018). Journal of Public Service Management, 1(2), 196-205.

Yudha, H., \& Susanto, TD (2019). E-Leadership: The Effect of E-Government Success in Indonesia. Journal of Physics: Conference Series, 1201(1). https://doi.org/10.1088/17426596/1201/1/012025

Yudianto, A., \& Nurpratama, M. (2021). Improvement of Business and Innovation in Small and Medium Industries (IKM) for Mekaya Losarang Products, Indramayu Regency. KANGMAS: Public Service Scientific Work, 2(2). Taken from http://journal.neolectura.com/index.php/kangma $\mathrm{s}$

Zamili M. (2015). Avoiding Bias: The Practice of Triangulation and the Validity of Qualitative Research. J Lisan Al-Hal. 2015; 7(2): 283-302. 